lightweight clay aggregate as components of container-plant growth media. J. Environ. Hort. 8:14-18.

Lamack, W.F. and A.X. Niemiera. 1993. Application method affects water application efficiency of spray stake-irrigated containers. HortScience 28:625-627.

Lieth, J.H. and D.W. Burger. 1989. Growth of chrysanthemum using an irrigation system controlled by soil moisture tension. J. Amer. Soc. Hort. Sci. 114:387-392.

Morvant, J.K., J.M. Dole, and J.C. Dole. 1998. Irrigation frequency and system affect poinsettia growth, water use, and runoff. HortScience 33:42-46.

Owen, J.S., Jr., S.L. Warren, and T.E. Bilderback. 2003. Clay amended pine bark influences irrigation volume and water buffering capacity. Proc. Southern Nursery Assn. Res. Conf., 48th Annu. Rpt. p. 20-23.

Poole, R.T. and C.A. Conover. 1982. Influence of leaching, fertilizer source and rate, and potting media on foliage plant growth, quality, and water utilization. J. Amer. Soc. Hort. Sci. 107:793-797.

Ruter, J.M. 1998. Pot-in-pot production and cyclic irrigation influence growth and irrigation efficiency of 'Okame' cherries. J. Environ. Hort. 16:159-162.

Schuch, U., R.A. Redak, and J. Bethke. 1995. Whole-plant response of six poinsettia cultivars to three fertilizer and two irrigation regimes. J. Amer. Soc. Hort. Sci. 121:69-76.

Tyler, H.H., S.L. Warren, and T.E. Bilderback. 1996a. Cyclic irrigation increases irrigation application efficiency and decreases ammonium losses. J. Environ. Hort. 14:194-198.

Tyler, H.H., S.L. Warren, and T.E. Bilderback. 1996b. Reduced leaching fractions improve irrigation use efficiency and nutrient efficacy. J. Environ. Hort. 14:199-204.

Urbano, C.C. 1989. The environmental debate: An industry issue. Amer. Nurseryman 184(4):69-85

Wanjura, D.F, D.R. Upchurch, and J.R. Mahan. 1995. Control of irrigation scheduling using temperature-time thresholds. Trans. Amer. Soc. Agr. Eng. 38:403-409.

Warren, S.L. and T.E. Bilderback. 1992. Arcillite: Effect on chemical and physical properties of pine bark substrate and plant growth. J. Environ. Hort. 10:63-69.

Warren, S.L. and T.E. Bilderback. 2002. Timing of low pressure irrigation affects plant growth and water utilization efficiency. J. Environ. Hort. 20:184-188.

Welsh, D.F. and J.M. Zajicek. 1993. A model for irrigation scheduling in container-grown nursery crops utilizing management allowed deficit (MAD). J. Environ. Hort. 11:115-118.

Whiteside, R. 1989. El Modeno Gardens: Innovative solutions to California's irrigation runoff restrictions. Grower Talks $59(2): 28-32$.

Wildon, C.E. and F.L.S. O'Rourke. 1964. The effect of arcillite in media for pot plants. Mich. State Univ. Res. Rpt. 16.

Yeager, T.H., C.H. Gilliam, T.E. Bilderback, D.C. Fare, A.X. Niemiera, and K.M. Tilt. 1997. Best management practices guide for producing containergrown plants. Southern Nursery Assn., Marietta, Ga.

Zur, B. 1976. The pulsed irrigation principle for controlled soil wetting. Soil Sci. 122:282-291.

\section{Modeling Irrigation Requirements for Landscape Ornamentals}

\author{
Richard C. Beeson, Jr.
}

AdDitional INDEX WORDS. nursery production, irrigation scheduling, woody ornamentals, water requirements

SUMMARY. In many sectors of agriculture, precision irrigation, applying only what water is needed for a given small area, has become a familiar term. Irrigation in most woody ornamental nurseries, though, has changed little since the 1960s. In many areas of the U.S., irrigation volumes required for nursery production have come under scrutiny due to projected, or real, competition for water with urban populations, or concerns over nursery runoff. Modeling of woody ornamental water use, and subsequent irrigation requirements, has been limited and focused mostly on trees. Previous research for modeling of non-tree water use is reviewed as an introduction to current efforts to develop models for precision irrigation of woody ornamentals. Pitfalls and limitations in current modeling efforts, along with suggestions for standardizing future research is emphasized. The latest model derived from recent research is presented.

W That is modeling? Modeling is the development of a mathematical description that imitates or emulates an entity based on data, postulates, and inferences (Merriam-Webster, 1991). In the case of irrigation modeling, it is estimating how much water should be applied in the upcoming irrigation event, based on conditions that have occurred since the crop was last irrigated. Fortunately, modeling of irrigation requirements has been studied intensively since early 1940s in agronomic crops (Thornth-

University of Florida, Institute of Food and Agricultural Sciences, Mid-Florida Research and Education Center-Apopka, 2725 S. Binion Road, Apopka, FL 32703.

This work was supported by the Florida Agricultural Experiment Station, and approved for publication as Journal Series R-10551. 
waite, 1944). This research resulted in development and acceptance of the simple, basic equation:

$$
\mathrm{ET}_{\mathrm{A}}=\mathrm{ET}_{\mathrm{O}} \times \mathrm{Kc}
$$

where $\mathrm{ET}_{\mathrm{A}}$ is the actual evapotranspiration of the area in question, in this case the container and plant system. $\mathrm{ET}_{\mathrm{O}}$ is the evapotranspiration from a reference crop of specific characteristics, subjected to identical microclimate conditions. $\mathrm{Kc}$ is defined as the crop coefficient, which relates $\mathrm{ET}_{\mathrm{O}}$ to $\mathrm{ET}_{\mathrm{A}}$. In practice, $\mathrm{Kc}$ is derived empirically from the ratio of $\mathrm{ET}_{\mathrm{A}}: \mathrm{ET}_{\mathrm{O}}$. The units of $\mathrm{ET}_{\mathrm{A}}$ and $\mathrm{ET}_{\mathrm{O}}$ are traditionally water depth, in inches or millimeters.

In the past, $\mathrm{ET}_{\mathrm{O}}$ was either measured using pan evaporation or calculated based on micrometeorology variables. In the 1940s, the mathematical model now known as the PenmanMonteith equation (Monteith, 1964; Penman, 1948) was first proposed. It has since become the standard for calculated $\mathrm{ET}_{\mathrm{O}}$. This energy balance equation requires inputs of solar radiation, temperature, relative humidity, and wind speed to calculate $\mathrm{ET}_{\mathrm{O}}$ for a theoretical crop. For nursery production, the short grass crop reference is used. Over recent decades the basic equation has remained the same, although subtle improvements have increased its precision. Pan evaporation relied on accurate measurements of the evaporation of water from a highly standardized pan (Class A) and rain events. Kc values were also derived from correlations of pan evapotranspiration with various crops. However, these Kcs are not compatible with those calculated from the PenmanMonteith equation. Of the two, the Penman-Monteith equation was more accurate, but required very expensive sensors and was difficult to calculate by hand. With common availability of computers and less expensive sensors, pan evaporation has not been reported since the early 1990s.

For any crop model to be used widely, an international standard for calculating $\mathrm{ET}_{\mathrm{O}}$ should be used. The most current international standard is the UN-FAO (United Nations Food and Agriculture Organization) 56 model (Allen et al., 1998). Currently, there are several Penman-Monteith models that differ so subtly that they provide the same values for $\mathrm{ET}_{\mathrm{O}}$ within the precision required for irrigation. One of these is the grass reference option in the ASCE 2000 equations (American Society of Civil Engineers, Reston, Va.). Another is the program provided by Campbell Scientific Inc. for its weather stations (Campbell Scientific, 1991). It uses the full ASCE Penman-Monteith equation (Jensen et al., 1990). Using updated standard calculations of $\mathrm{ET}_{\mathrm{O}}$ is important. Data collection for calculation of $\mathrm{Kc}$ can be an expensive and/or labor-intensive proposition. Therefore, such research will not be conducted everywhere; most locations will need to rely on models derived from other sites. With literally hundreds of woody ornamental species in production and thousands of cultivars, no one research group will be able to derive Kcs for all species, especially given the wide range of climatic zones and the limited number of zones in which most species will thrive. The literature suggests that, at best, models will need to be developed for groups of plants using representative species (Burger et al., 1987; Regan, 1997). Even then, the number of representative species will probably still be more numerous than the major agronomic, vegetable, and fruit crops.

WOODY ORNAMENTAL HISTORY. While modeling of $\mathrm{ET}_{\mathrm{A}}$ for agronomic crops has 60 years of research behind it, the first refereed papers on woody ornamental modeling appeared in the early 1980s. In one of the first, Fitzpatrick (1980) used the Thornthwaite equation (Thornthwaite, 1944) to calculate $\mathrm{ET}_{\mathrm{O}}$, then used it to develop a model for the tropical woody ornamental weeping fig (Ficusbenjamina). The Thornthwaite equation estimates $\mathrm{ET}_{\mathrm{O}}$ as an exponential function of mean monthly temperature and a fraction of annual heat index. To relate the model to other size plants and species, Fitzpatrick included a relative size index of $\mathrm{SI}_{\mathrm{S}} / \mathrm{SI}_{\mathrm{F}}$, where $\mathrm{SI}$ = canopy height plus average width. $\mathrm{SI}_{\mathrm{S}}$ was the size index of the plant in question and $\mathrm{SI}_{\mathrm{F}}$ was the size index of the weeping fig he used:

$$
\mathrm{ET}_{\mathrm{A}}=\left(0.35 \times \mathrm{ET}_{\mathrm{REF}}-0.12\right)\left(\mathrm{SI}_{\mathrm{S}} \div \mathrm{SI}_{\mathrm{F}}\right)
$$

When this model was tested against other weeping figs over a 2month period, the model prediction underestimated $\mathrm{ET}_{\mathrm{A}}$ by $27 \%$ in July and overestimated it by $8 \%$ in August. For 14 other species, calculated $\mathrm{ET}_{\mathrm{A}}$ ranged from an overestimation of $46 \%$, to an underestimation of $123 \%$. (Fitzpatrick, 1980). In addition to poor estimates of $\mathrm{ET}_{\mathrm{A}}$ of other species, other problems plagued this model. First, the Thornthwaite equation is a relatively simple equation for calculating $\mathrm{ET}_{\mathrm{O}}$, and is based on historical data rather than real-time data. Furthermore, the Thornthwaite equation estimates $\mathrm{ET}_{\mathrm{O}}$ on a monthly basis. Thus, it is not responsive to variations in climatic conditions over periods shorter than 1 month and does not permit daily modification in irrigation scheduling due to clouds, temperature fluctuations, etc. The innovation initialized by Fitzpatrick was the use of the relative size index, which attempted to adjust the model output based on plant size.

In 1987, Burger, in conjunction with several colleagues, reported Kc for several species of woody ornamentals in 1-gal $(3.8 \mathrm{~L})$ containers at several locations in California (Burger et al., 1987). In their calculations, they used a version of the Penman-Monteith equation used by local California Irrigation Management and Information System (CIMIS) stations. These Kc values were for species of marketable size. The Kc values published ranged from 1.2 to 5.1 and were given for each species in a pot-to-pot and spaced configuration. Kc values were higher for all species in the spaced vs. pot-to-pot configuration. At the time and currently, Kc values for all other crops, including tree crops, are generally less than 1.0. This exemplifies the primary problem with modeling $\mathrm{ET}_{\mathrm{A}}$ of container plants. In containers, $\mathrm{ET}_{\mathrm{A}}$ is measured by weight loss from a container initially near $100 \%$ container capacity. This provides $\mathrm{ET}_{\mathrm{A}}$ as a volume. $\mathrm{ET}_{\mathrm{O}}$ is calculated as a depth, in millimeters or $1 / 100$ inch. For in-ground crops, $\mathrm{ET}_{\mathrm{A}}$ and $\mathrm{Kc}$ are based on irrigated area or a ground area basis, which includes most of the root system and all the canopy. However, for container plants, canopy projected surface areas generally exceed container surface areas, often several fold. While transpiration occurs throughout the canopy, only water that reaches the container surface is available to the plant. When measured as a volume, $\mathrm{ET}_{\mathrm{A}}$ has to be normalized by an area to be of the same units as $\mathrm{ET}_{\mathrm{O}}$ for the calculation of Kc. Since irrigation has to reach a container surface, Burger et al. (1987) opted to normalize ET based on container surface area, hence the higher Kc values compared to all other species. While the Kc presented in their paper could be used to estimate 
irrigation requirements for plants nearing marketable size, or for worse case planning purposes for total production cycle, they are not useful for estimating daily irrigation needs until plants approach marketable size. One of the most important aspects of this research is that it appears different species may be grouped by similar $\mathrm{ET}_{\mathrm{A}}$.

A similar approach was taken by Regan (1977) in the early 1990s for more northerly species. Like Burger et al., Regan developed Kc for plants in 1-gal containers and covered a wide range of species. Regan took the additional step of using $\mathrm{Kc}$ to catagorize the species into five water use groups. Unlike Burger et al., Regan derived Kc periodically during the production cycle from liners to marketable size plants. From this, he provided a range of $\mathrm{Kc}$ for plants both in the early pot-to-pot configuration and, later, container-spaced configuration. Despite a very different mix of species, the Kc values reported by Regan were comparable to those reported by Burger et al. While Regan's Kc related to plants throughout the production period, the range of individual species Kc was large and there was no information to associate this to plant growth, either by time or canopy size.

Later, Schuch and Burger (1997) presented models developed over a 1to 2-year production period for several woody ornamentals grown in 5-gal $(18.9$ L) containers, again normalizing $\mathrm{ET}_{\mathrm{A}}$ based on container surface. While the models were developed using $\mathrm{ET}_{\mathrm{O}}$ and time of production with good correlations, each species required its own equation. In order to deal with the cyclic nature of seasons across years, time was converted using a Fourier curve. While this approach was successful in dealing with multiple sigmoidal growth cycles as a result of multiple-year production periods, it led to a second complication. Because this model was based on production time, its accuracy if applied to future conditions, such as different species, different locations, or even repeated in the same location with same species, will depend on how closely the growth rates match. Accelerated or delayed growth rates that could occur from different climatic or cultural practices would affect canopy size and its interaction with $\mathrm{ET}_{\mathrm{O}}$. Thus, basing $\mathrm{ET}_{\mathrm{A}}$ models on time, whether production time or calendar, places

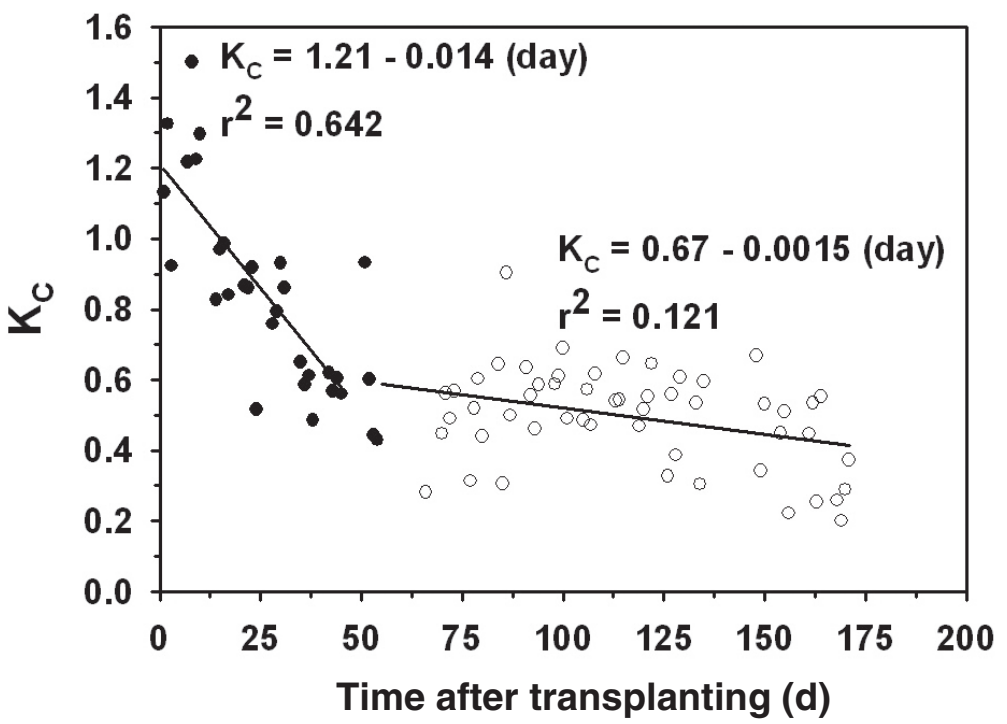

Fig. 1. Changes in the crop coefficient $(\mathrm{Kc})$ based on canopy projected surface area (CPSA) based on time after transplant of common ligustrum from 1-gal $(3.8 \mathrm{~L})$ containers in to 3 -gal $(11.4 \mathrm{~L})$ containers. Each point represents a single plant replicate. Only the line with an $r^{2}=0.642$ was the slope and constant significant $(P<0.05)$.

restrictions on the model's accuracy and applicability.

An alternative approach to normalizing $\mathrm{ET}_{\mathrm{A}}$ based on container diameter is to base it on a plant canopy's projected surface area (CPSA). Beeson (1996) showed that when $\mathrm{ET}_{\mathrm{A}}$ was normalized by both $\mathrm{ET}_{\mathrm{O}}$ and CPSA, essentially calculating $\mathrm{Kc}$ based on CPSA, Kc declined with time after upcanning of spaced containers, becoming constant during the latter period of production (Fig. 1). This was the mirror image of what has been reported for developing agronomic crops, where Kc initially increases as plant canopies grow, then becomes relatively constant once canopies close and cover the soil surface (Doss et al., 1962). For the container-grown plants, $\mathrm{Kc}$ declined as the production bed approached canopy closure, and became relatively constant after canopy closure (Beeson, 1996). Fitting an equation to this curve would produce a model for predicting irrigation needs that would address some of the criticisms of earlier modeling efforts, although it would still be of limited use since the calculated Kc value would be a function of time after potting. Thus, any variations in canopy growth relative to the plants used to develop the model would erode its reliability and accuracy. The strong relationship, however, between plant canopy size, canopy closure, and $\mathrm{ET}_{\mathrm{O}}$ suggested a potential avenue for modeling $\mathrm{ET}_{\mathrm{A}}$ that would solve several of the problems previously indicated, including the dependency on time.

To capitulate, any modeling of nursery plant $\mathrm{ET}_{\mathrm{A}}$ must be based on current models of $\mathrm{ET}_{\mathrm{O}}$ that have been standardized worldwide. While there are numerous species of plants grown, it appears they can be categorized based on Kc such that only models for representative species will need to be developed. To be universally applied, $\mathrm{ET}_{\mathrm{A}}$ models should not be directly based on time.

In view of the limitations of previous efforts to model container plant $\mathrm{ET}_{\mathrm{A}}$, and the promising associations between $\mathrm{ET}_{\mathrm{A}}, \mathrm{ET}_{\mathrm{O}}, \mathrm{CPSA}$, and canopy closure, an effort was put forward to develop a model for the latter associations (Beeson, 2004). The model was derived from $\mathrm{ET}_{\mathrm{A}}$ data collected on common ligustrum (Ligustrum japonica) from the transplanting of rooted cuttings into 3-gal (11.4 L) containers until at least $92 \%$ of measured plants obtained marketable size nearly a year later. The first $30 \mathrm{~d}$ after potting were not included in the model because evaporation from the container surface accounted for most, if not all, of the $\mathrm{ET}_{\mathrm{A}}$ during this period (Beeson, 2004).

The model of $\mathrm{Kc}$ as a function of percentage of canopy closure (percent closure) was exponential and highly correlated (Fig. 2). The decline in Kc 


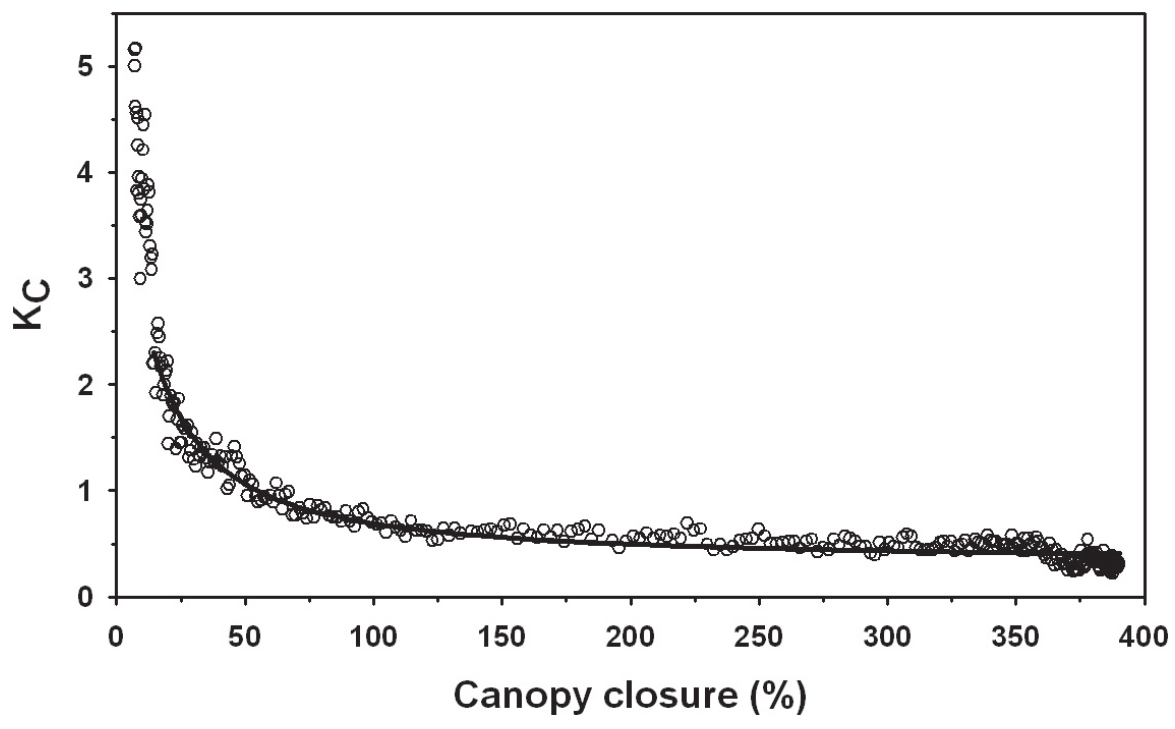

Fig. 2. Crop coefficient $(\mathrm{Kc})$ based on actual evapotranspiration $\left(\mathrm{ET}_{\mathrm{A}}\right)$ normalized by canopy projected surface area (CPSA) as a function of percent canopy closure. Each point represents seven plant replicates. The solid line was generated from the fitted equation shown in the figure.

in the early stages of plant growth, along with further marginal declines after $100 \%$ canopy closure, parallel those reported by Beeson (1996) for plants in 1 -gal containers transplanted into 3 -gal containers, but reported as a function of time (Fig. 1). The mean Kc after $100 \%$ canopy closure $(0.3)$ is similar to that reported for marketable-size azaleas under closed canopy conditions (Beeson, 1993).

The methodology used to develop this model is proposed as a basis for future modeling efforts for woody ornamentals and container-grown plants in general. Relative to the results of previous research on modeling $\mathrm{ET}_{\mathrm{A}}$ of woody plants, this methodology has several advantages. Since the calculation of Kc is based on canopy closure, it should be independent of plant growth rates and therefore regional or yearto-year climatic differences. Canopy closure only proceeds as fast as plant growth. Theoretically, canopy closurebased models should be independent of container size and spacing between containers, within limits. Using a canopy-based, rather than time-based function avoids the need to use Fourier curve transformations to account for changes in $\mathrm{ET}_{\mathrm{A}}$ or growth with season. If the percent closure or canopy area does not change, neither should the relationship of $\mathrm{ET}_{\mathrm{A}}$ to $\mathrm{ET}_{\mathrm{O}}$. This would account for periods of canopy dormancy. Finally, development of models based on canopy components should be easier to convert to predictive irrigation models than those that require complex transformations or provide $\mathrm{Kc}$ ranges only.

To use this model, one would need to periodically determine average canopy area and calculate percent closure based on container size and spacing. Using current percent closure, Kc would be calculated. This Kc would then be multiplied by CPSA (square centimeters) and $\mathrm{ET}_{\mathrm{O}}$ (centimeters) to estimate the volume of $\mathrm{ET}_{\mathrm{A}}$ (milliliters) on a daily basis. Estimated $\mathrm{ET}_{\mathrm{A}}$ could then be applied through microirrigation or divided by container surface area to derive an equivalent irrigation depth. Only during the first months between transplant establishment and development of $100 \%$ canopy closure would frequent adjustment to the Kc value need to be made. However, CPSA would need to be updated to account for plant growth.

Unfortunately, while the methodology used in the development of this model appears to provide a sound platform for modeling container-grown plant $\mathrm{ET}_{\mathrm{A}}$, the actual model derived will likely not be a universal model for all woody ornamentals. As shown previously by Burger et al. (1987) and Regan (1997), diverse species will require several different categories of relative water use, and therefore several models of representative species will likely be needed.

While the model presented is strong, it does not account for all the water used by a plant.

Since $\mathrm{ET}_{\mathrm{A}}$ was based on weight changes, some water lost by $\mathrm{ET}_{\mathrm{A}}$ is offset by increases in fresh mass accumulation. This can be estimated from the data and, fortunately, was quite small on a day-to day-basis for shrubs 24 to 30 inches (61.0 to 76.2 $\mathrm{cm}$ ) high. This may not be the case for large trees. Determining how much water the plant/container system has lost during the course of a day is only part of the equation in estimating irrigation application rates. Irrigation uniformity should be factored in when determining application rates to ensure uniform plant growth. In addition, if irrigation is supplied by overhead sprinklers, canopy shedding increases as a function of canopy interaction, or overlap (Beeson and Yeager, 2003). Thus, as canopies increase in size and transpire more water, they also tend to shed more overhead irrigation to the outside of the container. While the negative effects of canopy overlap are known for plants of marketable size, the development of canopy shedding as a function of percent closure is unknown and requires further research.

\section{Literature cited}

Allen, R.G., L.S. Pereira, D. Raes, and M. Smith. 1998. Crop evapotranspiration: Guidelines for computing crop water requirements. Irr. Drainage Paper 56. Food Agr. Org. United Nations, Rome.

Beeson, R.C., Jr. 1993. Relationship of potential evapotranspiration and actual evapotranspiration of Rhododendron sp. 'Formosa'. Proc. Fla. State Hort. Soc. 106:274-276.

Beeson, R.C., Jr. 1996. Penman crop coefficients for container grown landscape ornamentals. Proc. Intl. Conf. Evapotranspiration and Irr. Scheduling. C.R. Camp, E.J. Sadler, and R.E. Yoder (eds.). San Antonio, Texas, 3-6 Nov. 1996. p. 257-262.

Beeson, R.C., Jr. 2004. Modeling actual evapotranspiration of Ligustrum japonica from rooted cuttings to commercially marketable plants in 12 liter black polyethylene containers. Acta Hort. In press.

Beeson, R.C., Jr. and T.H. Yeager. 2003. Plant canopy affects sprinkler irrigation application efficiency of container-grown ornamentals. HortScience 38:1373-1377.

Burger, D.W., J.S. Hartin, D.R. Hodel, T.A. Lukaszewski, S.A. Tjosvoid, and 


\section{WORKSHOP}

S.A. Wagner. 1987. Water use in California's ornamental nurseries. Calif. Agr. $41(9 / 10): 7-8$.

Campbell Scientific. 1991. Application note 4-D. Campbell Sci., Logan, Utah.

Doss, B.D., O.L. Bennett, and D.A. Ashely. 1962. Evapotranspiration by irrigated corn. Agron. J. 54:497-498.

Fitzpatrick, G. 1980. Water budget determinations of container-grown ornamental plants. Proc. Fla. State Hort. Soc. 93:166-168.

Jensen, M.E., R.D. Burman, and R.G. Allen (ed.). 1990. Evapotranspiration and irrigation water requirements. Amer. Soc. Civil Eng., Eng. Practice Manual No. 70.

Merriam-Webster. 1991. Webster's ninth new collegiate dictionary. Merriam-Webster, Springfield, Mass.
Monteith, J.L. 1964. Evaporation and environment. State and movement of water in living organisms. Symp. Soc. Expt. Biol. 19:205-234.

Penman, H.L. 1948. Natural evaporation from open water, bare soil and grass. Proc. Royal Soc. London A. 193:120-146.

Regan, R. 1997. Grouping containergrown plants by water use. Digger 4l(6):24-27.

Schuch, U.K. and D.G. Burger. 1997. Water use and crop coefficients of woody ornamentals in containers. J. Amer. Soc. Hort. Sci. 122:727-734.

Thornthwaite, C.W. 1944. Report of the committee on transpiration and evaporation, 1943-44. Trans. Amer. Geophys. Union 25:683-693. 